\title{
Overview on chromatographic and potentiometric based approaches for $p K a$ determination of sparingly soluble substances
}

\author{
Natalija Nakov $^{1}{ }^{*}$, Jelena Acevska $^{1}$, Katerina Brezovska ${ }^{1}$, Aneta Dimitrovska ${ }^{1}$ \\ ${ }^{1}$ Institute of Applied Chemistry and Pharmaceutical Analysis, Faculty of Pharmacy, \\ Ss. Cyril and Methodius University, 1000 Skopje, Republic of Macedonia \\ Received: February 2018; Accepted: April 2018
}

\begin{abstract}
The dissociation constant $(\mathrm{pKa})$ is one of the most important physicochemical property of the compounds and it is of great importance for the pharmaceutical industry. Many of the active pharmaceutical ingredients are sparingly soluble in water or have no chromophore, thus the conventional UV/Vis spectrometry and potentiometry methods are not applicable. This article presents an overview of several approaches based on RP-HPLC and cosolvent/surfactant potentiometry that have been recently published for the $p K a$ determination of sparingly soluble active pharmaceutical ingredients. Additionally, different calculation methods that have been used for the estimation of the aqueous dissociation constant are summarized.
\end{abstract}

Keywords: dissociation constant, pKa, sparingly soluble substances, determination, reverse-phase liquid chromatography, potentiometry, surfactants

\section{Introduction}

The dissociation constant $(p K a)$ is one of the primary physicochemical property of active pharmaceutical ingredients. The accurate measurement of the $p K a$ value is of great importance to a wide range of research fields. The pharmacokinetics (ADMET: adsorption, distribution, metabolism, excretion and toxicity) of active pharmaceutical ingredients depend on their $p K a$ value. The determination of the $p K a$ value during the early stage studies could provide proper selection of a candidate for active pharmaceutical ingredient among the large number of compounds produced by combinatory chemistry. The knowledge of the $p K a$ value for the analyte and its related impurities is essential for analytical method development; providing ruggedness and faster method optimization

\footnotetext{
*natalijan@ff.ukim.edu.mk
}

(Avdeef, 2001; Kerns \& Di, 2004; Manallack, 2007).

Several techniques are used for determination of the dissociation constant. Computational methods are valuable tool for $p K a$ calculation, especially for large set of compounds present in the screening stage of the drug candidate. There are several computer programs (such as $p K a$ Pallas program, $\mathrm{ACD} / \mathrm{pKa}, \mathrm{CSpKa}$ Predictor, ADME/Tox WEB, etc.) which are based on different theoretical approaches for predicting the $p K a$ value. It should be noted that the accuracy of the computational methods depends only on the model used to perform the calculations. However, computational methods could give unreliable results for sparingly soluble compounds (Babic et al., 2007; Reijenga et al., 2013; Špirtović-Halilović \& Zavrśnik, 2010).

Traditionally, UV/Vis spectrometry and potentiometry have been standard methods for the pKa determination (Erdemgli et al., 2007). The UV/Vis 
spectrometric method offers great precision, but it hinges on a $\mathrm{pH}$ dependent spectrum of the compound in question. It means that a presence of a chromophore close to the ionization site in the molecule is needed. Additional requirement of this technique is that the tested compound should be pure or its impurities should not absorb in the UV/Vis range, since overlapping spectra could be obtained (Babic et al., 2007; Demiray et al., 2012; Pandey, 2013; Reijenga et al., 2013). Potentiometry is the method of choice for the $p K a$ determination of water soluble compounds. This technique offers great precision, accuracy and fast determination. The major drawback is the requirement of larger quantity of pure compound having a water solubility of at least $10^{-4} \mathrm{M}$ (Babic et al., 2007; Narasimham et al., 2011; Reijenga et al., 2013).

In the last twenty years, there is a growing interest for the reverse-phase high performance liquid chromatography (RP-HPLC) as a method for the $p K a$ determination, based on the relationship between the capacity factor and the $\mathrm{pH}$ value of the mobile phase (Babic et al., 2007; Manderscheid \& Eichinger, 2003; Uhrova et al., 1997; Wiczling et al., 2004). The increased application of this technique for the $\mathrm{pKa}$ determination is due to the several advantages, including very small quantity of sample is required, the solubility is not a concern and the purity of the compound is not a question.

Many active pharmaceutical ingredients are sparingly soluble in water, thus the $p K a$ determination could not be performed in pure water, and thus waterorganic mixtures are needed. It is well established that the increase of the organic content in water-organic mixtures leads to suppression of the basic analyte $p K a$ and to an increase in the acidic analyte $p K a$ (Kazakevich \& Lobrutto, 2007). In such case, the obtained $p K a$ values are referred as apparent $p K a\left({ }_{w}^{s} p K_{a}\right)$ values and consequently an estimation of the aqueous $p K a\left({ }_{w}^{w} p K_{a}\right)$ value is needed (Babic et al., 2007; Manderscheid \& Eichinger, 2003; Uhrova et al., 1997).

Generally, the RP-HPLC techniqueand modifications of the potentiometric titration are the methodological approaches of choice for the $p K a$ determination of sparingly soluble compounds. This review article, describes the principles, advantages and drawbacks on several approaches based on RP-HPLC and potentiometry which are recently used for this purpose. Additionally, an overview of different approaches for estimation of the aqueous $p K a$ values is given.

\section{RP-HPLC approaches for $p K a$ determination}

\section{Isocratic RP-HPLC approach}

The HPLC methodological approach of the $p K a$ determination is based on the assumption that the neutral and ionic forms of the compound have different chromatographic behavior. The determination of $p K a$ value by means of HPLC was first reported by Horvath et al. (1977) and by Van de Venne et al. (1978). The most widely used HPLC procedure for the $p K a$ determination is the isocratic HPLC approach (Babic et al., 2007; Manderscheid \& Eichinger, 2003; Uhrova et al., 1997). This approach involves a series of isocratic experiments at different $\mathrm{pH}$ value of the mobile phase, using at least three different concentration of the organic modifier (acetonitrile or methanol) in the mobile phase (Demiray et al., 2012; Erdemgli et al., 2007; Gumustas et al., 2010; Huo et al., 2013; Kazakevich \& Lobrutto, 2007). More accurate results could be obtained if lower organic modifier concentration is used, thus the organic modifier concentration in the mobile phase should not be more than $40 \%$. The selected organic modifier concentration in the mobile phase should be able to elute the neutral form in a reasonable time, while providing a value for the retention factor $\left(k\right.$ ') of the ionized form of at least one. The ${ }_{w}^{s} p K_{a}$ value could be determined using nonlinear regression analysis software, such as NLREG program (Demiralay et al., 2009, Gumustas et al., 2010; Şanli et al., 2010) where the plot $k$ ' versus $\mathrm{pH}$ value at a particular organic content concentration is fitted to a nonlinear symmetrical sigmoidal model. The inflection point of the curve corresponds to the ${ }_{w}^{s} p K_{a}$ value of the compound.

The drawback of the isocratic concept is that long retention times could be observed using low organic content mobile phases. Additionally, 8 to 10 experiments should be performed at each organic content composition, which makes this concept a time-consuming (Babic et al., 2007; Wiczling et al., 2004). Beforehand the column stability was the limiting factor for the range of the $p K a$ values that could be determined. However, nowadays there is variety of stationary phases with wide $\mathrm{pH}$ stability range that could fit this purpose, so the chromatographic column stability is not an issue anymore. The isocratic RP-HPLC approach is applicable for simultaneous $p K a$ determination of small number of compounds, thus this approach is not a method of choice for early stage screening of drug candidates.

\section{Gradient RP-HPLC approach}

The methodology for the gradient RP-HPLC determination of $p K a$ is based on two organic solvent gradient runs and one $\mathrm{pH}$ gradient RP-HPLC run (Kaliszan \& Wiczling, 2010; Wiczling et al., 2004; Wiczling et al., 2006, Wiczling et al., 2008). The initial organic solvent gradient experiments at two different gradient times should be carried out at fixed $\mathrm{pH}$ value, where the ionization of the compound is suppressed $(\mathrm{pH}$ 3.0 for acidic and $\mathrm{pH} 10.5$ for basic compounds). These organic solvent gradient runs are intended to define the organic solvent concentration, needed for providing appropriate retention time for completing the $\mathrm{pH}$ gradient experiment. Afterwards, a programmed $\mathrm{pH}$ gradient experiment is carried out at the chosen organic solvent 
concentration in the mobile phase. The $\mathrm{pH}$ gradient should be started at $\mathrm{pH}$ value that ensures complete suppression of the ionization of the compounds and it ends at a $\mathrm{pH}$ value that provides their full ionization. This means that the $\mathrm{pH}$ gradient experiment for acidic compound should be started at $\mathrm{pH} 3.0$ and finished at $\mathrm{pH}$ 10.5. At the end, one isocratic experiment at $\mathrm{pH}$ value that ensures a complete ionization of the compound is needed in order to obtain the retention of the ionized form of the compound.

The described procedure has the advantage of fast $p K a$ determination of large set of substances in a mixture. Additional increase of the number of analyzed compounds in individual run could be gained with the replacement of the UV detector with time-of-flight mass spectrometry (TOF-MS) detector. Recently, a gradient RP-HPLC-TOFMS method has been published for determination of the hydrophobicity and dissociation constant of mixture of 40 compounds (Wiczling et al., 2014). The same research team expands the applicability of the proposed method on a diverse group of 161 chemical compounds (Wiczling et al., 2015). Some of the $p K a$ values derived with this methodology differ from the literature data; therefore, the gradient RP-HPLC approach is useful for a rough, preliminary estimation of the $p K a$ values of drug candidates.

\section{Solely aqueous RP-HPLC approach}

Recently, a new RP-HPLC approach based on solely aqueous mobile phase was published (Volna et al., 2017). The mobile phase is composed of $100 \%$ modified BrittonRobinson buffer, where the $\mathrm{pH}$ of the eluent is set by mixing the Britton-Robinson buffer with diethylamine $(0.1 \% v / v)$ in the HPLC pump. In case of very lipophilic compounds, $5 \%$ methanol could be added to the mobile phase. This methodology is applicable for compounds having wide range of lipophilicity ( $\log \mathrm{P}$ from -2.26 to 2.26). The use of the solely aqueous mobile phase avoids the need of $p K a$ determination at several sets of measurements in eluent at different organic solvent content, which speeds up the procedure. Another advantage of this methodology is that the there is no need to use more complex calculation, such as YasudaShedlovsky extrapolation (Shedlovsky, 1962), for the estimation of the ${ }_{w}^{w} p K_{a}$ value. Also, it should be emphazed that good agreement between the $p K a$ values derived with this procedure and literature values was encountered for acidic compounds. Hence, the solely aqueous RP-HPLC approach presents a promising approach for fast and relatively simple approach for $p K a$ determination of large number of compounds.

\section{Potentiometric approaches for $p K a$ determination}

The potentiometry is a well-established method for $p K a$ determination. The simplicity and the low cost of the potentiometric titrations have made it one of the most commonly used methods for $p K a$ determination. However, the poor solubility of the compounds impedes the traditional potentiometric determination, thus alternative approaches are needed.

\section{Cosolvent (mixed-solvent) approach}

The cosolvent approach is based on the measurements of the apparent dissociation constant in different ratios of organic solvent/water mixtures where the ${ }_{w}^{w} p K_{a}$ value is obtained by extrapolation (Avdeef et al., 1999; Fallaven \& Schapoval, 1997; Takacs-Novak et al., 1997). According to the reported literature data, the potentiometric titrations could be performed by use of different organic solvents, such as: methanol (Erdemly et al., 2007; Fallavena \& Schapoval, 1997; HerreroMartinez et al., 2008; Takacs-Novak et al., 1997), dioxane (Fallavena \& Schapoval, 1997), acetone (Fallavena \& Schapoval, 1997; Takacs-Novak et al., 1997), isopropyl alcohol (Rafols et al., 1997). However, methanol has the widest application for the purpose because the solvation effect of this solvent is closest to water (Avdeef, 1993a; Avdeef, 1993b; Takacs-Novak et al., 1997; Völgyi et al., 2007).

However, some compounds could not be dissolved in single organic solvent/water mixture. To overcome this problem, Völgyi and coworkers (2007) proposed a multicomponent cosolvent (MDM-water mixture) approach. The MDM-water mixture consists of $60 \% \mathrm{v} / \mathrm{v}$ MDM stock solution (equal volumes of methanol, dioxin and acetonitrile) and $40 \% v / v$ water (and $0.15 \mathrm{M} \mathrm{KCl}$, for ionic strength adjustment), and this mixture improves the solubility of the compounds. Consequently, the $p K a$ measurements could be performed using lower proportions of organic solvent which allows sidestep of the long-distance extrapolations to zero organic solvent. Hence, more reliable results could be obtained. The applicability of the MDM-water mixture approach was confirmed through the $p K a$ detrmination of compounds having diverse structure (Völgyi et al., 2007; Zapala, 2011).

The apparent ionization constant obtained with the cosolvent approach could be deduced graphically from the Bjerrum plots, $n_{H}^{-}$vs $\mathrm{pH}$ (Aldeef, 2003; Kraft, 2003), where the Bjerrum function, $\bar{n}_{H}^{-}$, is the average number of bound protons at particular $\mathrm{pH}$ and the $\mathrm{p} K_{\mathrm{a}}$ value is read from the Bjerrum plot at $n_{H}^{-}=0.5$.

\section{Surfactant based approach}

Generally, the cosolvent concept is more timeconsuming. Recently, an alternative approach using nonionic surfactants is proposed (Ravichandiran et al., 2011). In this study, the desired solubility of the poorly 
soluble compounds was achieved using low concentrations $(2-5 \%)$ of Tween 80, Chemophol and Labrasol. The authors of this concept demonstrated that the ionization behavior of several compounds remains unaffected by the use of the nonionic surfactants, with the same level of accuracy without a need of extrapolations to pure water.

However, several literature reports revealed that cationic (cetyltrimethylammonium bromide), anionic (sodium dodecyl sulfate) and non-ionic (Triton X100) micellar solutions shift the dissociation equilibrium as compared to those in pure water (Jaiswal et al., 2005; Nemcova et al., 2009; Yuangin et al., 2002). In case of cationic and anionic surfactant solution, electrostatic effect and polarity effect have an impact on dissociation equilibrium, as for non-ionic surfactants the polarity is the dominant factor. Generally, the $p K a$ shifts are smaller when nonionic surfactants are used. This suggests that measurements using different concentration of nonionic surfactant should be performed in order to perceive their effect on the dissociation constant.

\section{Estimation of aqueous $p K a$ value}

The literature data suggest that several approaches could be used for the estimation of the ${ }_{w}^{w} p K_{a}$ value. One of the most commonly used approach for the ${ }_{w}^{w} p K_{a}$ value estimation is based on the linear relationship between the ${ }_{w}^{s} p K_{a}$ values and the volume fraction of the organic solvent used for the determination. The intercept of the linear equation (extrapolation to pure water mobile phase) presents the ${ }_{w}^{w} p K_{a}$ value of the compound.

The second method known as Yasuda-Shedlovsky extrapolation establishes linear relationship between the apparent $\mathrm{pKa}$ and the solvent dielectric constant (Sheldovsky, 1962), following the equation:

$$
{ }_{\mathrm{w}}^{\mathrm{s}} \mathrm{pK}_{\mathrm{a}}+\log \left[H_{2} O\right]=\frac{\alpha}{\varepsilon}+\beta
$$

where ${ }^{s} \varepsilon$ denotes the solvent dielectric constant, $\left[\mathrm{H}_{2} \mathrm{O}\right]$ is the molar concentration of water in the mobile phase, and $\alpha$ and $\beta$ are constants.

The plot of ${ }_{w}^{s} p K_{a}$ value $+\log \left[\mathrm{H}_{2} \mathrm{O}\right]$ versus $1 / /^{\mathrm{s}} \varepsilon$ is extrapolated to a value corresponding to pure water $\left(\varepsilon=78.3,\left[\mathrm{H}_{2} \mathrm{O}\right]=55.5\right)$. The ${ }_{w}^{w} p K_{a}$ value could be calculated from the equation 1 , using the obtained value for slope and intercept as $\alpha$ and $\beta$ constants, respectively. This method is most widely used procedure for cosolvent techniques, such as isocratic RP-HPLC and cosolvent potentiometry procedure (Demiray et al., 2012; HerreroMartinez et al., 2008; Völgyi et al., 2007; Wiczling et al., 2004; Zapala, 2011).
The ${ }_{w}^{w} p K_{a}$ value could be calculated using the empirical equation (Eq.2 - Eq. 4) presented by Algelov et al. (2008).

$$
\begin{aligned}
& \mathrm{k}_{\mathrm{obs}}=\frac{\mathrm{k}_{\mathrm{HA}}+k_{A} * 10^{p H-p K_{a}}}{1+10^{p H-p K_{a}}} \text { (for acidic compounds) Eq. } 2 \\
& \mathrm{k}_{\mathrm{obs}}=\frac{\mathrm{k}_{\mathrm{B}}+k_{B H^{*}} 0^{p K_{a}-p H}}{1+10^{p K_{a}-p H}} \text { (for basic compounds) Eq. } 3
\end{aligned}
$$

where $\mathrm{k}_{\mathrm{HA}}, \mathrm{k}_{\mathrm{B}}$ and $\mathrm{k}_{\mathrm{A}}{ }^{-}, \mathrm{k}_{\mathrm{BH}}{ }^{+}$are the neutral and ionic forms of the compound, respectively.

The conversion formula is as follows:

$$
p K_{a}=p H-\frac{\log \left(k_{H A}-k\right)}{k-k_{A}}
$$

where $\mathrm{k}_{\mathrm{HA}}$ and $\mathrm{k}_{\mathrm{A}}{ }^{-}$are $\mathrm{k}^{\prime}$ of the neutral and ionic form of the compound, respectively; the $\mathrm{k}_{\mathrm{HA}}$ is the minimum value of $\mathrm{k}^{\prime}$ and $\mathrm{k}_{\mathrm{A}}{ }^{-}$is the maximum one. The $\mathrm{pH}$ and $\mathrm{k}$ values are defined as points at maximum slope of the $\mathrm{pH}-\mathrm{k}$ ' plot. Huo et al. (2013) applied this method to determine the $p K a$ value of oxysophocarpine. This procedure was also used to calculate the $p K a$ value of compound with wide range of lipophilicity using the solely aqueous RP-HPLC approach (Volna et al., 2017).

Another empirically based approach takes into account the type (acetonitrile or methanol) and concentration of the organic modifier. For acetonitrile/water mobile phase the aqueous $p K a$ could be calculated by the following equations:

$$
\begin{array}{ll}
{ }_{\mathrm{w}}^{\mathrm{w}} \mathrm{pK}_{\mathrm{a}}={ }_{w}^{S} p K_{a}+(x \% \text { organic }) * A & \text { Eq. } 5 \\
{ }_{\mathrm{w}}^{\mathrm{w}} \mathrm{pK}_{\mathrm{a}}={ }_{w}^{s} p K_{a}+(x \% \text { organic }) * B & \text { Eq. } 6
\end{array}
$$

The value of $\mathrm{A}$ is 0.03 and the value of $\mathrm{B}$ is 0.02 and they correspond to acidic and basic $p K a$ shift per $10 \%$ ACN, respectively (Kazakevich \& Lobrutto, 2007). This calculation is applicable only for the isocratic RP-HPLC approach.

\section{Conclusion}

Several RP-HPLC and potentiometric based approaches are available for the determination of the $p K a$ value of sparingly soluble active pharmaceutical ingredients.

The isocratic RP-HPLC is simple and easy approach for the $p K a$ determination of compounds in simple mixtures. Although it is a time-consuming, this approach gives very accurate results. Recently solely aqueous RPHPLC has emerged as a simple alternative approach. However, more literature data are required to evaluate the reliability of the $p K a$ data obtained using this approach. 
The gradient RP-HPLC concept is more applicable for rough estimation of the $p K a$ value. The gradient RPHPLC/MS methodological approach is useful for a preliminary evaluation of the drug candidates, considering the short analysis time.

The cosolvent potentiometric approach is a wellestablished procedure for the $p K a$ determination of pure, sparingly soluble compounds. The major disadvantage of this concept could be seen in the large number of experiments needed for the determination and in the complexity of calculations for estimation of the aqueous $p K a$ value. The surfactant concept appears as a simpler approach and it has a great potential, but additional investigation that include a larger number of compounds is needed.

This overview contributes to the enrichment of the scientific data related to the alternative chromatographic and potentiometric based approaches for determination of sparingly soluble active pharmaceutical ingredients.

\section{References}

Angelov, T., Vlasenko, A., Tashkov, W., 2008. HPLC determination of $\mathrm{pKa}$ of parabens and investigation on their lipophilicity parameters. J. Lid. Chromatogr. Relat. Technol. 31, 188-197. Available at: https://doi.org/10.1080/10826070701738787.

Avdeef, A., 1993a. pH-metric log P. Refinement of partition coefficients and ionization constants of multiprotic substances. J. Pharm. Sci., 82, 183-190. Available at: https://doi.org/10.1002/jps.2600820214.

Avdeef, A., Corner, J.E.A., Thomson, J.S., 1993b. pH-metric $\log$ P 3. Glass electrode calibration in methanol-water, applied to $\mathrm{pKa}$ determination of water-insoluble substances. Anal. Chem. 65, 42-49. Available at: https://doi.org/10.1021/ac00049a010.

Avdeef, A., Box, K.J., Comer, J.E.A., Hadley, M., Hibbert, C., 1999. pH-metric $\log \mathrm{P} 11$. pKa determination of waterinsoluble active pharmaceutical ingredients in organic solvent-water mixtures. J. Pharm. Biomed. Anal. 20, 631641. Available at: https://doi.org/10.1016/s07317085(98)00235-0.

Avdeef, A., 2001. Physicochemical profiling (solubility, permeability and charge state). Curr. Top. Med. Chem. 1, 277-351. Available at: https://doi.org/10.2174/1568026013395100.

Aldeef, A., 2003. Absorption and Drug Development. WileyInterscience: Hoboken, New Jersey.

Babic, A., Horvat, A., Pavlovic, M.D., Kastelan-Macan, M., 2007. Determination of $\mathrm{pKa}$ values of active ingredients. Trends Anal. Chem. 26, 1043-1061. Available at: https://doi.org/10.1016/j.trac.2007.09.004.

Demiray, E.Ç., Alsancak, G., Ozkan, A.S., 2009. Determination of $\mathrm{pKa}$ values of nonsteroidal antiinflamatory drug-oxicams by RP-HPLC and their analyses in pharmaceutical dosage forms. J. Sep. Sci. 32, 2928-2936. Available at: https://doi.org/10.1002/jssc.200900234.

Demiray, E.Ç., Koç, D., Daldal, Y.D., Çakir, C., 2012. Determination of chromatographic and spectrophotometric dissociation constant of some beta lactam antibiotics. J.
Pharm. Biomed. Anal. 71, 139-143. Available at: https://doi.org/10.1016/j.jpba.2012.06.023.

Erdemgil, F.Z., Şanli, S., Şanli, N., Özkan, G., Barbosa, J., Guiteras, J., Beltrán, J.L., 2007. Determination of pKa values of some hydroxylated benzoic acids in methanolwater binary mixtures by LC methodology and potentiometry. Talanta 72, 489-496. Available at: https://doi.org/10.1016/j.talanta.2006.11.007.

Fallavena, P.R., Schapoval, E.E., 1997. pKa determination of nimesulide in methanol-water mixtures by potentiometric titrations. Int. J. Pharm. 158, 109-112. Available at: https://doi.org/10.1016/S0378-5173(97)00221-4.

Gumustas, M., Şanli, S., Şanli, N., Ozkan, S., 2010. Determination of $\mathrm{pKa}$ values of some antihypertensive active pharmaceutical ingredients by liquid chromatography and simultaneous assay of lercanidipine and enalapril in their binary mixtures. Talanta 82,1528 1537. Available at: https://doi.org/10.1016/j.talanta.2010.07.037.

Herrero-Martinez, J.M., Repolles, C., Bosch, E., Roses, M., Rafols, C., 2008. Potentiometric determination of aqueous dissociation constant of flavonols sparingly soluble in water. Talanta 74, 1008-1013. Available at: https://doi.org/10.1016/j.talanta.2007.08.007.

Horvat, C., Melander, W., Molnar, I., 1977. Liquid chromatography of ionogenic substances with nonpolar stationary phases. Anal. Chem. 49, 142-154. Available at: https://doi.org/10.1021/ac50009a044.

Huo, H., Li, T., Zhang, L. 2013. pKa determination of oxysophocarpine by reversed-phase high performance liquid chromatography. SpringerPlus 2, 270. Available at: https://doi.org/10.1186/2193-1801-2-270.

Jaiswal, P.V., Ijeri, V.S., Srivastava, A.K., 2005. Effect of surfactants on the dissociation constant of ascorbic and maleic acids. Colloids Surf B Biointerfaces 46, 45-51. Available at: https://doi.org/10.1016/j.colsurfb.2005.09.001.

Kaliszan, R., Wiczling, P., 2010. Gradient reversed-phased high-performance chromatography of ionogenic analytes. Trends Anal. Chem. 30, 1372-1381. Available at: https://doi.org/10.1021/ac034999v.

Kazakevich, Y., Lobrutto, R., 2007. HPLC for pharmaceutical scientists, fourth Ed. John Willey \& Sons, Inc.: Hoboken, New Jersey.

Kerns, E.H., Di, L., 2004. Physicochemical profiling: overview of the screens. Drug Discov. Today Technol. 1, 343-348. Available at: https://doi.org/10.1016/j.ddtec.2004.08.011.

Kraft, A., 2003. The determination of the pKa of multiprotic, weak acids by analyzing potentiometric acid-base titration data with difference plots. J. Chem. Ed. 80, 554-559. Available at: https://doi.org/10.1021/ed080p554.

Kubik, L., Struck-Lewicka, W., Kaliszan, R.Wiczling, P., 2015. Simultaneous determination of hydrophobicity and dissociation constant for a large set of compounds by gradient reverse phase high performance liquid chromatography-mass spectrometry technique. J. Chromatogr. A 1416, 31-37. Available at: https://doi.org/10.1016/j.chroma.2015.09.003.

Manallack, D.T., 2007. The pKa Distribution of Active pharmaceutical ingredients: Application to Drug Discovery. Perspec. Medicin. Chem. 1, 25-38.

Manderscheid, M., Eichinger, T., 2003. Determination of pKa values by Liquid Chromatography. J. Chrom. Sci. 41, 323-

Макед. фарм. билт., 63 (2) 21 - 27 (2017) 
326. Available at:

https://doi.org/10.1093/chromsci/41.6.323.

Narasimham, L., Barhate, V.D., 2011. Physico-chemical characterization of some beta blockers and anti-diabetic active pharmaceutical ingredients - potentiometric and spectrophotometric $\mathrm{pKa}$ determination in different cosolvents. Eur. J. Chem. 2, 36-46. Available at: https://doi.org/10.5155/eurjchem.2.1.36-46.371.

Némcova, I., Rychlovský P., Pudilová, D., 2009. Effect of surfactants and ionic strength on dissociation constant of hydrochlorides of phenothiazine derivates. Anal. Lett. 42, 646-658. Available at: https://doi.org/10.1080/00032710902722046.

Pandey, M.M., Jaipal, A., Kumar, A., Malik, R., Charde, S.Y., 2013. Determination of pKa of felodipine using UV-Vis spectroscopy. Spectrochim. Acta A Mol. Biomol. Spectrosc, 115, 887- 890. Available at: https://doi.org/10.1016/j.saa.2013.07.001

Rafols, C., Roses, M., Bosch, E., 1997. Dissociation constant of several non-steroidal anti-inflammatory active pharmaceutical ingredients in isopropyl alcohol/water mixtures. Anal. Chim. Acta 350, 249-255. Available at: https://doi.org/10.1016/S0003-2670(97)00307-3.

Ravichandiran, V., Devarajan, V., Masilamani, K., 2011. Determination of ionization constant $(\mathrm{pKa})$ for poorly soluble active pharmaceutical ingredients by using surfactants: a novel approach. Pharm. Lett. 3, 183-192.

Reijenga, A., Van Hoof, A., Van Loon, A., Teunissen, B., 2013. Development of methods for determination of $\mathrm{pKa}$ values. Anal. Chem. Insights 8, 53-71. Available at: https://doi.org/10.4137/ACI.S12304.

Şanli, N., Şanli, S., Ozkan, G., Denizli, A., 2010. Determination of $\mathrm{pKa}$ of some sulfonamides by LC and LC-PDA methods in acetonitrile-water binary mixtures. J. Braz. Chem. Soc. 21, 1952-1960. Available at: http://dx.doi.org/10.1590/S0103-50532010001000022.

Sheldovsky, T., 1962. in Peasce, B. (Eds), Electrolytes. Pergamon Press, New York.

Špirtović-Halilović, S., Zavrśnik, D., 2010. Computer programs for calculating pKa: a comparative study for 3-(3-(2nitrophenyl) prop-2-enoyl)-2H-1-benzopyran-2-one. J. Serb. Chem. Soc. 75, 243-248. Available at: https://doi.org/10.2298/JSC1002243S.

Takacs-Novak, K., Box, K.J., Avdeef, A., 1997. Potentiometric $\mathrm{pKa}$ determination of water-insoluble compounds: validation study in methanol/water mixtures. Int. J. Pharm. 151, 235-248. Available at: https://doi.org/10.1016/S03785173(97)04907-7.

Van de Venne, J.L.M., Hendrix J.L.H.M., Deeler, R.S., 1978.
Retention behavior of carboxylic acids in reverse-phase column liquid chromatography. J. Chromatogr. 167, 1-16. Available at: https://doi.org/10.1016/S0021-9673(00)91142-7.

Völgyi, G., Ruiz, R., Box, K., Comer, J., Bosch, E., TakacsNovák, K., 2007. Potentiometric and spectrophotometric $\mathrm{pKa}$ determination of water-insoluble compounds: Validation study in a new cosolvent system. Anal. Chim. Acta, 583, 418-428. Available at: https://doi.org/10.1016/j.aca.2006.10.015.

Volna, T., Motyka, K., Hlavác, J., 2017. RP-HPLC determination of dissociation constant using solely aqueous mobile phase. J. Pharm. Biomed. Anal. 134, 143148. Available at: https://doi.org/10.1016/j.jpba.2016.11.038.

Uhrova, M., Miksik, I., Deyl, Z., Bellini, S., 1997. Determination of dissociation constants by separation methods (HPLC and CE). Theoretical background and guidelines for application. Process Contr. Qual. 10, 151167.

Yuanqin, Z., Fan, L., Xiaoyan, L., Jing, L., 2005. The effect of surfactant micelles on the dissociation constant and transition points and transition intervals of acid-base indicators. Talanta 56, 705-710. Available at: https://doi.org/10.1016/s0039-9140(01)00618-x.

Wiczling, P., Markuszewski, M.J., Kaliszan, R., 2004. Determination of $\mathrm{pKa}$ by $\mathrm{pH}$ gradient reversed-phase HPLC. Anal. Chem. 76, 3069-3077. Available at: https://doi.org/10.1021/ac049807q.

Wiczling, P., Kawczak, P., Nasal, A., Kaliszan, R., 2006. Simultaneous determination of $\mathrm{pKa}$ and lipophilicity by gradient RP HPLC. Anal. Chem. 78, 239-249. Available at: https://doi.org/10.1021/ac0512103.

Wiczling, P., Markuszewski, M.W., Markuszewski, M.J., Kaliszan, R., 2008. The application of gradient reversephase liquid chromatography to the $\mathrm{pKa}$ and $\log \mathrm{kw}$ determination of polyprotic analytes. J. Chromatogr. A $1214,109-114$

Wiczling, P., Struck-Lewicka, W., Kubik, L., Siluk, D., Markuszewski, M.J., Kaliszan, R., 2014. The simultaneous determination of hydrophobicity and dissociation constant by liquid chromatography-mass spectrometry. J. Pharm. Biomed. Anal. 94, 180-187. Available at: https://doi.org/10.1016/j.jpba.2014.01.038.

Zapala, L., 2011. Potentiometric studies on the equilibria of flufenamic acid in aqueous solutions and in two-phase organic solvent+water systems. J. Solution Chem. 40, 198-210. Available at: https://doi.org/10.1007/s10953010-9642-6. 


\title{
Преглед на хроматографски и потенциометриски методи за определување на $p K a$ вредност на слабо растворливи супстанции
}

\author{
Наталија Наков $^{1 *}$, Јелена Ацевска ${ }^{1}$, Катерина Брезовска $^{1}$, Анета Димитровска ${ }^{1}$ \\ ${ }^{1}$ Институт за применета хемија и фармацевтски анализи, Фармацевтски Факултет, \\ Универзитет „Св. Кирил и Методиј”, 1000 Скопје, Македонија
}

Клучни зборови: константа на дисоцијација, рКа, слабо растворливи супстанции, определување, реверзно-фазна течна хроматографија, потенциометрија, сурфактанти

Константата на дисоцијација $(p K a)$, како една од најважните физичко-хемиски својства на активните супстанции, има големо значење за фармацевтска индустрија од повеќе аспекти. Повеќето активни супстанции се нерастворливи во вода или немаат хромофор, поради што не се применливи конвенцијалните техники (UV/Vis спектрометрија и потенциометрија) за определување на константата на дисоцијација. Во овој ревијален труд даден е преглед на новите пристапи што се користат за определување на $p K a$ вредноста на слабо растворливите супстанции, со посебен осврт на реверзно-фазната течна хроматографија и на потенциометриски титрации во присуство на корастворувач/сурфактант. Дополнително, даден е осврт на различни пристапи што се применуваат за пресметување на константата на дисоцијација. 
